\title{
Analisis Likuiditas Dan Struktur Keuangan Terhadap Kinerja Keuangan Pada Perusahaan Telekomunikasi Yang Terdaftar Di Bursa Efek Indonesia
}

\author{
Indra Maulana ${ }^{1)}$, Lidya Martha ${ }^{2)}$ \\ Sekolah Tinggi Ilmu Ekonomi KBP \\ Email: Indram243@gmail.com \\ Email Pembimbing: lidyam83@gmail.com
}

\begin{abstract}
This research as a purpose to know what influence of liquidity and solvency ratio toward profitability ratio. Sample from this research is four enterprise in Indonesian Stock Exchange period 2007-2016. The data analysis technique used multiple linear regression analysis using Eviews 6.From the results of tests performed showed that liquidity statistically not significant affect profitability, as indicated by the probability of >0,05 is 0,6022. Same diffirent with solvency who were statistically not significantly affect profitability, which is indicated by the probability of $>0,05$ is 0,1273 .
\end{abstract}

Keywords: Liquidity, Solvency, Profitability.

\section{PENDAHULUAN}

Semakin berkembangnya sistem teknologi informasi dan bertambah luasnya ilmu pengetahuan, maka semakin bertambah ketatnya persaingan didunia usaha, untuk membuat perusahaan harus bekerja lebih efektif dan efesien agar perusahaan mampu menjaga aktifitas operasinya sekaligus meningkatkan kinerja keuangan untuk mendapatkan hasil yang optimal bagi perusahaan.

Kinerja perusahaan merupakan kemampuan perusahaan dalam setiap menghasilkan laba dari setiap aktitivitas kegiatan operasinya dalam beberapa periode waktu tertentu.

Menurut Fauzi (1995:207) "Kinerja merupakan suatu istilah umum yang digunakan sebagian atau seluruh tindakan aktifitas dari suatu organisasi pada suatu periode,seiring dengan referensi dalam jumlah standar seperti biaya-biaya masa lalu atau yang diproyeksikan,suatu dasar dan semacam nya”.
Analisis rasio keuangan dipakai sebagai sistim peringatan awal (Early Warning System) terhadap kemunduran kondisi keuangan dari suatu perusahaan. Analisis rasiodapat membimbing investor membuat keputusan atau pertimbangan tentang apa yangakan dicapai oleh perusahaan dan atau bagaimana prospek yang akan dihadapi dimasayang akan datang. Sesuai dengan beragam jenis kegunaan informasi akuntansi, maka jenis-jenis rasio laporan keuangan yang digunakan oleh si pengambil keputusantergantung pada jenis keputusan yang akan dibuat dan metode pengambilan keputusanyang digunakan (Dewanti,2010).

Analisis rasio keuangan merupakan analisis awal yang digunakan untuk menilai kinerja keuangan perusahaan secara umum. Contohnya rasio likuiditas yang dapat digunakan untuk mengukur kemampuan perusahaan untuk memenuhi kewajiban jangka pendek perusahaan dan rasio profitabilitas dapat dipakai untuk 
mengukur tingkat keuntungan yang diperoleh perusahaan.

Penelitian yang dilakukan oleh Moch. Djoehar Ainun pada perusahaan Telekomunikasi yang terdapat di Bursa Efek Indonesia periode 2009-2013 hanya PT. Telkom yang memiliki kinerja keuangan yang stabil dengan rasio likiditas, solvabilitas dan profitabilitas. Sedangkan pesaingnya memiliki kinerja keuangan yang tidak stabil atau berfluktuatif.

Pada penelitian lain tentang pengaruhlikuiditas dansolvabilitas terhadap profitabilitaspadaperusahaanReal Estate dan Property Bursa Efek Indonesia tahun 2005-2012yang ditelitioleh ErmaRisdo Tohonan Manurung,Gusnardi,RinaSelva Johan(2012)menunjukkanbahwa secara simultan likuiditas dan solvabilitas berpengaruh secarasignifikan terhadap profitabilitas,secaraparsial likuiditastidak berpengaruh signifikan terhadap profitabilitas dan secara parsialsolvabilitasberpengaruh signifikan terhadap profitabilitas. Dan penelitian Abdul Kadir (2012) menyatakan bahwa current ratio dan debt to equity ratio tidak mempunyai pengaruh yang siqnifikan terhadap net profit margin.

Berdasarkan latar belakang dirumuskan masalah yaitu apakah pengaruh current ratiao dan debt to equity ratio terhadap net profit margin.

\section{LANDASAN TEORI\& HIPOTESIS}

Laporan Keuangan merupakan ringkasandari suatu proses pencatatan, ringkasan dari transaksi-transaksi keuangan yang terjadi selama tahun buku yang bersangkutan. Laporan keuangan ini dibuat oleh manajemen dengan maksud untuk mempertanggungjawabkan tugastugas yang dibebankan kepadanya oleh para pemilik perusahaan. Disamping itu laporan keuangan dapat juga digunakan untuk memenuhi maksud-maksud lain yaitu sebagai laporan kepada pihak-pihak diluar perusahaan (Baridwan, 2004:17).

Laporan keuangan pada dasarnya adalahhasil dari proses akuntansi yang dapat digunakan sebagai alat untuk berkomunikasi antar data keuangan atau aktifitas suatu perusahaan dengan pihakpihak yang berkepentingan dengan data atau aktifitas perusahaan tersebut (Munawir, 1995:2).

Menurut Riyanto (2008:327), dalam bukunya dasar-dasar pembelanjaan perusahaan menyatakan bahwa laporan keuangan adalah sebagai laporan finansial (financial statement), memberikan ikhtisar mengenai keadaan finansial suatu perusahaan, dimana neraca (balance sheet) mencerminkan nilai aktiva, utang dan modal sendiri pada suatu saat tertentu, dan laporan rugi laba (income statement) mencerminkan hasilhasil yang dicapai selama suatu periode tertentu, biasanya meliputi periode satu tahun.

Rasio likuiditas merupakan rasio untuk mengukur kemampuan dalam memenuhi kewajiban jangka pendeknya pada saat ditagih oleh suatu perusahaan. Dengan kata lain dapat membayar kembali pencairan dana depositnya pada saat ditagih serta dapat mencukupi permintaan kredit yang telah diajukan (Kasmir,2013: 130). Rasio likuiditas ini terdiri dari(Kasmir, 2013:134-142) :

a. Rasio Lancar (Current Ratio)

Pengertian dari current ratio adalah rasio yang dihasilkan dari perbandingan antara aktiva lancar dengan utang jangka pendek. Current ratio yang baik dan memuaskan perusahaan adalah sebesar 200\%, artinya bahwa setiap utang lancar Rp 1 akan dijamin dengan aktiva lancar 
sebesar Rp 2. Jika current ratio suatu perusahaan hanya $90 \%$, maka setiap utang lancar sebesar Rp 1 akan dijamin dengan aktiva lancar sebesar Rp0,9,sehingga perusahaan ini disebut dalam keadaan ilikuid (Kasmir,2013).

Current Ratio $=($ Aktiva Lancar $/$ Utang Lancar ) x $100 \%$

b. Rasio Cepat (Quick Ratio)

Pengertian Quick Ratio adalah hasil perbandingan antara aktiva lancar dikurangi persediaan dengan total kewajiban jangka pendek. Quick Ratio sebesar $100 \%$ sudah menunjukan baiknya kondisi keuangan jangka pendek suatu perusahaan (Kasmir,2013).

Quick Ratio $=\{$ (Aktiva Lancar Persedian) / Utang Lancar\} x 100\%

c. Rasio Kas (Cash Ratio)

Rasio kas atau cash ratio merupakan alat yang digunakan untuk mengukur seberapa besar uang kas yang tersedia untuk membayar hutang lancar (Kasmir,2013).

Cash Ratio $=($ Kas $/$ Total Kewajiban Lancar ) x $100 \%$

d. Inventory to Net Working Capital

Rasio ini digunakan untuk mengukur atau membandingkan antara jumlah persediaan yang ada dengan modal kerja perusahaan (Kasmir,2013).

$I N W C=\{$ Persediaan $/$ ( Aktiva lancar Utang Lancar $)\} \times 100 \%$

Menurut Kasmir (2010:151) rasio solvabilitas atau leverage ratio merupakan rasio yang digunakan untuk mengukur sejauh mana aktiva perusahaan dibiayai dengan utang. Artinya seberapa besar beban utang yang ditanggung perusahaan dibandingkan dengan aktivanya.

$$
\text { Menurut Riyanto (2001), }
$$

solvabilitas adalah kemampuan suatu perusahaan untuk membayar semua hutang- hutangnya, baik jangka pendek maupun jangka panjang. Suatu perusahaan dikatakan solvabel apabila perusahaan tersebut mempunyai aktiva atau kekayaan yang cukup untuk membayar semua hutang-hutangnya pada saat perusahaan itu likuidasi tetapi tidak dengan sendirinya perusahaan itu likuid.

Solvabilitas adalah kemampuan perusahaan untuk memenuhikewajibankeuangannya apabila perusahaan tersebut dilikuidasikan, baik kewajiban jangkapendek maupunjangka panjang(Munawir,2002:32).Rasio yang digunakan untuk menganalisis tingkat solvabilitas adalah:

a. Rasio Hutang Terhadap Total Aktiva (Debt to Assets Ratio)

Rasio ini menunjukan besarnya biaya total aktiva yang pembiayaannya berasal dari total utang. Semakin tinggi resiko ini berarti semakin besar jumlah pinjaman yang digunakan untuk membiayai aktiva. Sebaliknya semakin rendah rasio ini berarti semakin kecil jumlah pinjaman yang digunakan untuk membiayai aktiva perusahaan (Kasmir,2013).

DAR $=($ Total Hutang $/$ Total Aset $) \mathrm{x}$ $100 \%$

b. Rasio Hutang Terhadap Ekuitas (Debt To Equity Ratio)

Rasio ini menunjukan jaminan yang diberikan modal sendiri atas utang yang diterima perusahaan (Jusuf,2014). Jika utang jangka panjang lebih besar daripada modal atau diatas $100 \%$, berarti sebagian besar biaya aktiva tetap dibiayai oleh utang jangka panjang, dan tingkat resiko keamanan usaha semakin besar dalam jangka panjang. Sebaliknya, jika modal lebih besar atau dibawah $100 \%$, berarti sebagian besar biaya aktiva tetap dibiayai oleh modal dan tingkat 
resiko keamanan usaha semakin kecil dalam jangka panjang (Kasmir,2013). DER $=($ Total Utang / Ekuitas $) \quad \mathrm{x}$ $100 \%$

c. Long-Term Debt To Equity Ratio

LDER merupakan rasio antara utang jangka panjang dengan modal sendiri dan hasil perhitungannya menunjukkan seberapa besar bagian dari setiap modal sendiri dijadikan jaminan untuk hutang jangka panjang (Kasmir,2013).

LDER = ( Utang jangka Panjang / Modal Sendiri ) x 100\%

Pengertian dari profitabilitas adalah kemampuan perusahaan untuk memperoleh keuntungan dari usahanya. Disini permasalahannya adalah keefektifan manajemen dalam menggunakan baik total aktiva maupun aktiva bersih. Keefektifan dinilai dengan mengaitkan laba bersih terhadap aktiva yang digunakan untuk menghasilkan laba (Sunyoto:2013).

Rasio profitabilitas atau sering disebut Rentabilitas suatu perusahaan menunjukkan kemampuan suatu perusahaan untukmenghasilkan laba dengan modal yangditanamkan di dalam perusahaan tersebut. Pada rasio-rasio profitabilitas, seluruh pengukuran rasio akan menunjukkan kondisi yang lebih baik jika jumlahnya atau angkanya semakin besar. Sebaliknya menunjukkan kondisi yang semakin jelek jika angka rasionya semakin kecil (Riyanto,2004: 335). Rasio yang digunakan dalam menganalisis tingkat profitabilitas adalah: a. Net Profit Margin

Net Profit Margin pada dasarnya mencerminkan efektifitas biaya atau harga dari kegiatan perusahaan. Profit margin dimaksudkan untuk mengetahui efisiensi perusahaan dengan melihat kepada besar kecilnya laba usaha dalam hubungannya dengan penjualan (Riyanto, 2008). $N P M=($ Laba Sesudah Pajak / Penjualan Netto ) x $100 \%$

b. Hasil Pengembalian Investasi (Return On Investment /ROI)

Rasio ini mengukur keuntungan yang diperoleh dari hasil kegiatan perusahaan (net income) dengan jumlah investasi atau aktiva yang digunakan setelah dikurangi bunga dan pajak (EAT) untuk menghasilkan keuntungan yang diinginkan (total assets).Bentuk paling mudah dari analisis rasio profitabilitas adalah menghubungkan laba bersih atau pendapatan bersih dengan total aktiva di neraca (Sunyoto, 2013).

$R O I=($ Laba Sesudah pajak / Jumlah Aktiva ) x $100 \%$

c. Hasil Pengembalian Ekuitas (Return On Equity/ ROE)

Hasil pengembalian ekuitas atau return on equity atau rentabilitas modalsendiri merupakan rasio untuk mengukur laba bersih (net income) sesudah pajak dengan modal sendiri.

Rasio yang paling umum untuk mengukur hasil pengembalian atas investasi pemilik modal adalah hubungan antara laba bersih setelah pajak dengan modal sendiri, (Sunyoto,2013)

$R O E=($ Laba Sesudah pajak / Jumlah Modal Sendiri ) x 100\%

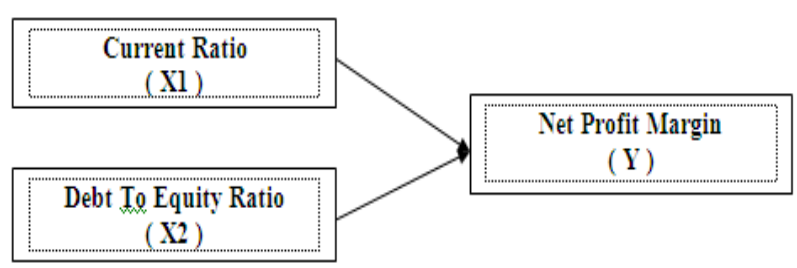




\section{Hipotesis}

Menurut Kasmir (2010:151) rasio solvabilitas atau leverage ratio merupakan rasio yang digunakan untuk mengukur sejauh mana aktiva perusahaan dibiayai dengan utang. Profitabilitas adalah kemampuan perusahaan untuk memperoleh keuntungan dari usahanya (Danang Sunyoto, 2013). Kedua rasio tersebut sangat berhubungan karena jika perusahaan tersebut mampu membayar hutang jangka panjangnya, maka perusahaan tersebut termasuk kepada perusahaan yang baik dalam menghasilkan laba.

M. Khafidz (2013) melakukan penelitian tentang pengaruh likiditas dan solvabilitas terhadap profitabilitas pada perusahaan sub sektor Telekomunikasi yang terdaftar di Jakarta Islamic Index (JII) periode 2010-2014 dan teknik analisis data menggunakan regresi linier.

M.Khafidz menemukan bahwa solvabilitas berpengaruh signifikan terhadap profitabilitas. Ruzaini (2012) juga melakukan penelitian tentang pengaruh likuiditas dan solvabilitas terhadap rentabilitas pada Koperasi Pegawai Republik Indonesia Bakti Husada tahun 2008-2012 dengan menggunakan teknik analisisdata regresi linier berganda. Ruzaini juga menemukan bahwa solvabilitas berpengaruh signifikan terhadap profitabilitas.

Nidya (2013) justru menemukan hasil yang berbeda. Dia melakukan penelitian tentang pengaruh likuiditas dan solvabilitas terhadap profitabilitas pada perusahaan sub sektor MakanandanMinuman yangTerdaftardiBursaEfekIndonesia (BEI) periode 2006-2012 dengan jumlah sampel sebanyak 6 perusahaan dan menggunakan teknik analisis data regresi liniear berganda. Nidya menemukan bahwa solvabilitas tidak berpengaruh signifikan terhadap profitabilitas.

Dari uraian di atas, dapat dikembangkan hipotesis sebagai berikut:

H1 Diduga Current Ratio berpengaruh signifikan negatifterhadap Net Profit Margin padaperusahaantelekomunikasi yang terdaftar di Bursa Efek Indonesia.

H2Diduga Debt to Equity Ratio berpengaruh signifikan negative terhadap Net Profit Margin pada perusahaan telekomunikasi yang terdaftar di Bursa Efek Indonesia.

\section{METODE PENELITIAN}

Jenis penelitian yang ada dalam penelitian ini adalah penelitian deskriptif kuantitatif, yaitu merupakan penelitian yang bertujuan menjelaskan fenomena yang ada dengan menggunakan anakaangka untuk mencandarkan karasteristik individu atau kelompok (Syamsudin \& Damiyanti: 2011).

$\begin{array}{ccr}\text { Menurut } & \text { Cooper } & (2008: 374) \\ \text { menerangkan } & \text { populasi } & \text { adalah }\end{array}$ sekelompok dari elemen-elemen yang ingin disimpulkan.Populasi pada penelitian ini adalah perusahaan sektor telekomunikasi yang terdaftar di Bursa Efek Indonesia sebanyak 6 perusahaan. Sedangkan sampel adalah kelompok kasus, partisipan, kejadian, atau bukti yang terdiri atas target populasi, yang dipilih secara hati-hati untuk merepresentasikan populasiCooper (2008:711).

Sampel pada penelitian ini dipilih berdasarkan teknik pengumpulan sampel purposive samplingdi mana penelitian ini tidak dilakukan pada seluruh populasi, tapi terfokus pada target dengan mempertimbangkan kriteriakriteria tertentu yang telah dibuat terhadap objek yang sesuai dengan 
tujuan penelitian, dalam hal inipenelitian dilakukan pada perusahaan-perusahaan yang terdaftar di Bursa Efek Indonesia. Kriteria-kriteria tertentu yang telah dibuat oleh peneliti terhadap objek dalam penelitian ini adalah sebagai berikut:

1. Perusahaan-perusahaan yang terdaftar di Bursa Efek Indonesia periode tahun 2007-2016.

2. Perusahaan-perusahaan yang dimaksud adalah perusahaan yang bergerak di bidang layanan jasa telekomunikasi dan jaringan.

3. Perusahaan-perusahaan yang menerbitkan laporan keuangan secara periodik dan lengkap dari tahun 20072016.

4. Apabila tahun periode tersebut memiliki perhitungan rasio keuangan minus, maka satu periode tersebut tidak akan dimasukkan dalam penelitian atau dihilangkan.

Tabel 1.2 SampelPenelitian

\begin{tabular}{|c|c|c|}
\hline No & KodeSaham & Namaperusahaan \\
\hline 1 & TLKM & PT.TelekomunikasiTbk. \\
\hline 2 & ISAT & PT.IndosatTbk. \\
\hline 3 & EXCL & PT.XI AxiataTbk. \\
\hline 4 & FREN & PT.SmartfrenTbk. \\
\hline
\end{tabular}

Teknik pengumpulan data yang dilakukan adalah sebagai berikut :

1. Studi Pustaka, yaitu melakukan telaah, eksplorasi, dan mengkaji berbagai literatur pustaka yang relevan dengan penelitian.

2. Dokumentasi, yaitu dengan mencari dan mengumpulkan data-data dari Pojok Bursa Efek Indonesia (BEI). Data yang dikumpulkan berupa laporan keuangan PT. Indosat Tbk., PT. Telekomunikasi Indonesia Tbk.
(Persero), PT. XL Axiata Tbk dan PT. Smartfren Telecom Tbk. periode tahun 2007-2014.

Variabel penelitian (Sugiyono: 2004) adalah salah satu yang berbentuk apa saja yang ditetapkan oleh peneliti untuk dipelajari sehingga diperoleh informasi tentang hasil tersebut kemudian ditarik kesimpulannya.

\begin{tabular}{|c|c|c|c|}
\hline No & Variabel & Defenisi & Pengukuran \\
\hline 1 & Likuiditas & $\begin{array}{l}\text { Merupakan rasio yang } \\
\text { digunakan untuk } \\
\text { membandingkan } \\
\text { antara jumlah aset } \\
\text { lancardibagi dengan } \\
\text { jumlah hutang lancar. }\end{array}$ & $C R=\frac{\text { Aset Lancarx } 100 \%}{\text { Hutang Lancar }}$ \\
\hline 2 & Solvabilitas & $\begin{array}{l}\text { Merupakan rasio yang } \\
\text { digunakan untuk } \\
\text { membandingkan } \\
\text { antara jumlah seluruh }\end{array}$ & $D E R=\frac{\text { Total Hutang }}{\text { Total modal }} \times 100 \%$ \\
\hline & & $\begin{array}{l}\text { hutang dan dibagi } \\
\text { dengan jumlah seluruh } \\
\text { modal }\end{array}$ & \\
\hline \multirow[t]{2}{*}{3} & \multirow[t]{2}{*}{ Profitabilitas } & \multirow{2}{*}{$\begin{array}{l}\text { Merupakan rasio yang } \\
\text { digunakan untuk } \\
\text { membandingkan } \\
\text { antara jumlah laba } \\
\text { bersih setelah pajak } \\
\text { dan dibagi dengan } \\
\text { jumlah penjualan } \\
\end{array}$} & $\mathrm{NPM}=\frac{\mathrm{EAT}}{\text { Penjualan }} \times 100 \%$ \\
\hline & & & \\
\hline
\end{tabular}

Teknik analisis data yang digunakan oleh peneliti adalah:

Statistik deskriptif adalah penyajian data secara numerik. Statistik deskriptif menyajikan ukuran-ukuran numerik yang sangat penting bagi data sampel.

. Uji Stasioneritas

Stasioner merupakan suatu kondisi data time series yang jika rata rata, varian dan covarian dari perubah tersebut seluruhnya tidak dipengaruhi oleh waktu (Junaidi, 2012). Metode pengujian stasioneritas dan akar unit yang akan digunakan disini adalah metode Augmented Dickey Fuller (ADF) dan Phillips Perron (PP). 
Prosedur untuk mengetahui data stasioner atau tidak dengan cara membandingkan antara nilai statistik ADF atau PP dengan nilai kritis distribusi Mac Kinnon. Nilai statistik ADF atau PP ditunjukkan oleh nilai t statistik. Jika nilai absolut statistik ADF atau PP lebih besar dari nilai kritisnya, maka data yang diamati menunjukkan stasioner dan jika sebaliknya nilai statistik ADF atau PP lebih kecil dari nilai kritisnya maka data tidak stasioner

Uji asumsi klasik digunakan untuk mendapatkan penduga koefsien regresi yang mempunyai error terkecil atau model regresi yang dihasilkan adalah mempunyai sifat BLUE (Best Linier Unbiased Estimate) atau mempunyai sifat yang Linear, tidak bias dan varian minimum. Ada pun ujia sumsi klasik adalah sebagai berikut.

Uji normalitas adalah uji untuk melihat apakah distribusi data mengikuti pola distribusi normal atau tidak, atau menguji apakah dalam sebuah model regresi, variable dependen, variable independen, atau keduanya mempunyai distribusi normal atau tidak.

Uji Multikolinearitas yaitu uji hubungan sesama variabel bebas. Multikolinearitas adalah keadaan dimana variabel -variabel independen dalam persamaan regresi mempunyai korelasi (hubungan) yang erat satu sama lain.

Uji Autokorelasi digunakan untuk melihat ada tidaknya Autokorelasi. Autokorelasi adalah korelasi yang terjadi diantara anggotaanggota dari serangkaian pengamatan yang tersusun dalam data time series.

Pengujian heteroskedastisitas dilakukan untuk menguji apakah dalam model regresi terjadi kesamaan variance dari residual satu pengamatan ke pengamatan yang lain (Ghozali, 2005).

Penelitian ini menggunakan program Eviews untuk memperoleh semua nilai yang diinginkan pada model analisis regresi dan pengujian secara statistik. Data yang digunakan biasanya berskala interval atau rasio.

Persamaan regresi linear berganda sebagai berikut:

$Y=\alpha+\beta_{1} X 1+\beta_{2} X 2+e$

Keterangan:

$\mathrm{A}=$ Konstanta

$\beta=$ Koefisien regresi (nilai peningkatan ataupun penurunan)

$\mathrm{Y}=$ Net Profit Margin (NPM)

$\mathrm{X} 1=$ Current Ratio (CR)

$\mathrm{X} 2$ = Debt To Equity Ratio (DER)

Uji F digunakan untuk menguji pengaruh variabel independen yaituCurrent Ratio dan Debt To Equity Ratio secara bersama-sama terhadap variabel dependen yaituNet Profit Margin dari suatu persamaan regresi yang didasarkan pada nilai probabilitas $\mathrm{a}=0,05$ dengan kriteria pengujian sebagai berikut :

Jika probabilitas > 0,05 maka Ha ditolak, Ho diterima.

Jika probabilitas $<0,05$ maka Ha diterima Ho ditolak. 
Uji $\mathrm{t}$ digunakan untuk menguji pengaruh variabel independen secara parsial terhadap variabel dependen, yaitu pengaruh dari variabel independen (Rasio Likuiditas dan Rasio Solvabilitas) terhadap variabel dependen (Rasio Profitabilitas) yang didasarkan pada nilai probabilitas $\mathrm{a}=$ 0,05 dengan kriteria pengujian sebagai berikut :

Jika probabilitas $>0,05 \mathrm{Ha}$ ditolak, Ho diterima

Jika probabilitas $<0,05 \mathrm{Ha}$ diterima, Ho ditolak

Uji $\mathrm{R}^{2}$ digunakan untuk mengetahui hubungan antara Rasio Likuiditas dan Rasio solvabilitas Terhadap Rasio Profitabilitas. Koefisiendeterminasiberkisardarinolsa mpaidengansatu( $0 \leq \mathrm{R} 2 \leq 1)$. Hal iniberartibilaR2 $=0$ menunjukkantidakadanyapengaruhant aravariabeldependen, apabila R2 semakinbesarterhadapvariabeldepende ndanbila R2 semakinkecilmendekati 0 makadapatdikatakansemakinkecilnyap engaruhvariabelindependenterhadapva riabeldependen.

\section{HASIL DAN PEMBAHASAN}

\section{Deskripsi Statistik Variabel Penelitian}

Berdasarkan hasil analisis deskripsi statistik, maka akan ditampilkan karakteristik sampel yang digunakan didalam penelitian ini meliputi: jumlah sampel $(\mathrm{N})$, rata-rata sampel (mean), nilai maksimum, nilai minimum serta standar deviasi $(\sigma)$ untuk masing-masing variabel.
Tabel 4.1

Deskripsi Statistik Variabel Penelitian

\begin{tabular}{|c|c|c|c|c|c|}
\hline $\begin{array}{l}\text { Vari } \\
\text { abel }\end{array}$ & $\mathrm{N}$ & $\begin{array}{l}\text { Mini } \\
\text { mum }\end{array}$ & $\begin{array}{c}\text { Maksi } \\
\text { mum }\end{array}$ & Mean & $\begin{array}{c}\text { stand } \\
\text { ar } \\
\text { devia } \\
\text { si }\end{array}$ \\
\hline $\begin{array}{l}\text { Curr } \\
\text { ent } \\
\text { Rati } \\
\text { o \% }\end{array}$ & $\begin{array}{l}4 \\
0\end{array}$ & $\begin{array}{r}6.00 \\
0000\end{array}$ & $\begin{array}{c}427.4 \\
000\end{array}$ & $\begin{array}{c}70.69 \\
800\end{array}$ & $\begin{array}{r}65.2 \\
3995\end{array}$ \\
\hline $\begin{array}{l}\text { Debt } \\
\text { To } \\
\text { Equi } \\
\text { ty } \\
\text { Rati } \\
\text { o \% }\end{array}$ & $\begin{array}{l}4 \\
0\end{array}$ & $\begin{array}{r}1.25 \\
0000\end{array}$ & $\begin{array}{c}98.00 \\
000\end{array}$ & $\begin{array}{r}21.4 \\
2225\end{array}$ & $\begin{array}{r}31.9 \\
3259\end{array}$ \\
\hline $\begin{array}{l}\text { Net } \\
\text { Profi } \\
\mathrm{t} \\
\text { Mar } \\
\text { gin } \\
\%\end{array}$ & $\begin{array}{l}4 \\
0\end{array}$ & $\begin{array}{c}- \\
51.74 \\
000\end{array}$ & $\begin{array}{c}71.00 \\
000\end{array}$ & $\begin{array}{r}8.74 \\
0250\end{array}$ & $\begin{array}{r}18.2 \\
7188\end{array}$ \\
\hline
\end{tabular}

Sumber : Data Diolah, Lampiran 2.

Pada Tabel 4.1. diatas menunjukkan bahwa jumlah data yang digunakan dalam penelitian ini sebanyak 40 sampel data yang diambil dari Laporan Tahunan Publikasi sektor telekomunikasi yang tercatat di BEI periode 2007 hingga 2016.

Data rasio CR terendah (minimum) adalah 6.000000 persen terdapat pada perusahaan EXCL tahun 2008 dan yang tertinggi (maksimum) 427.4000 persen terdapat pada perusahaan FREN tahun 2007. kemudian rata-rata CR sebesar 70.69800 persen. Sementara standar deviasi sebesar 65.23995 menunjukkan simpangan data yang relatif kecil, karena nilainya yang lebih kecil dari pada nilai mean-nya yaitu sebesar 70.69800.

Data rasio DER terendah (minimum) adalah 1.250000 persen terdapat pada perusahaan TLKM tahun 2009 dan yang 
tertinggi (maksimum) 98.00000 persen terdapat pada perusahaan TLKM tahun 2010. kemudian rata-rata DER sebesar 21.42225 persen. Sementara standar deviasi sebesar 31.93259 persen menunjukkan simpangan data yang relatif besar, karena nilainya yang lebih besar dari pada nilai mean-nya yaitu sebesar 21.42225 .

Data rasio NPM mempunyai tingkat terendah (minimum) adalah 51.74000 persen terdapat pada perusahaan FREN tahun 2015 dan paling tinggi (maksimum) sebanyak 71.00000 persen terdapat pada perusahaan ISAT tahun 2014, kemudian rata-rata sebesar 8.740250 persen dengan nilai standar devias sebesar 18.27188 persen menunjukkan simpangan data yang relatif besar, karena nilainya yang lebih besar dari pada nilai mean-nya yaitu sebesar 8.740250 .

\section{Pengujian Stasioneritas}

Berdasarkan hasil analisis Uji Stasioneritas, maka akan ditampilkan karakteristik sampel yang digunakan di dalam penelitian ini meliputi: jumlah sampel (N), t statistik serta nilai probabilitas untuk masing-masing variabel. Standar agar sebuah data tersebut tersebut stasioner adalah probabilitas $<0,05$ atau $t$-statistic $>\mathrm{t}$ kritis.

\begin{tabular}{|c|c|c|c|}
\hline \multirow{2}{*}{$\begin{array}{c}\text { Variab } \\
\text { el }\end{array}$} & \multicolumn{3}{|c|}{ Tingkat Stasioneritas } \\
\cline { 2 - 4 } & $\begin{array}{c}\boldsymbol{t} \text { - } \\
\text { statistic }\end{array}$ & $\begin{array}{c}\text { Probabili } \\
\text { ty }\end{array}$ & $\begin{array}{c}\text { Keteran } \\
\text { gan }\end{array}$ \\
\hline \multirow{2}{*}{ CR } & - & & \\
& $\begin{array}{c}4.42986 \\
8\end{array}$ & 0.0012 & Stasioner \\
\hline \multirow{2}{*}{ DER } & - & & \\
& $\begin{array}{c}0.44623 \\
8\end{array}$ & 0.8904 & Tidak \\
\hline \multirow{2}{*}{ NPM } & - & & Stasioner \\
& 4.55074 & 0.0008 & Stasioner \\
\hline
\end{tabular}

Tabel 4.2

Uji Stasioneritas Variabel Penelitian

Sumber: Data diolah lampiran 3

Dilihat dari tabel 4.2 di atas prilaku data dari masing-masing variabel. Berdasarkan hasil pengujian Augmented Dickey-Fuller (ADF) pada tingkat level yang mencakup intercept, dapat dilihat bahwa variabel (DER) nilai absolut ADF nya lebih besar dari nilai kritis dengan derajat keyakinan 0.05. sehingga perlu dilakukan uji derajat intekrasi dan uji stasioneritas derajat difference sampai variabel yang diamati stasioner pada derajat yang sama.

Tabel 4.3

Hasil Uji Derajat Integrasi (First Difference)

\begin{tabular}{|c|c|c|c|}
\hline \multirow{2}{*}{ Variabel } & \multicolumn{3}{|c|}{ Tingkat Stasioneritas } \\
\cline { 2 - 4 } & \multicolumn{3}{|c|}{ difference } \\
\cline { 2 - 4 } & t-statistic & Probability & Keterangan \\
\hline \multirow{2}{*}{ CR } & $\begin{array}{c}- \\
4.429868\end{array}$ & 0.0012 & Stasioner \\
\hline DER & $\begin{array}{c}- \\
8.440848\end{array}$ & 0.0000 & Stasioner \\
\hline NPM & $\begin{array}{c}- \\
4.550744\end{array}$ & 0.0008 & Stasioner \\
\hline
\end{tabular}

Sumber : data diolah lampiran 3

Pada tabel di atas menunjukan hasil uji statistic ADF pada First 
Difference yang menujukan hipotesis nol ditolak, dengan kata lain dengan data pada variabel (DER) telah diturunkan satu kali data menjadi stasioner. Dengan ini nilai absolut lebih kecil dari nilai kritis pada tingkat keyakinan0.005.artinya varibel (DER) tersebut sudah tidak mengandung masalah akar unit dan mempunyai kondisi data stasioner pada tingkat atau derajat integrasi satu.

\section{Pengujian Asumsi Klasik \\ Pengujian Normalitas Data}

Uji normalitas adalah uji untuk melihat apakah distribusi data mengikuti pola distribusi normal atau tidak, atau menguji apakah dalam sebuah model regresi, variabel dependen dan variabel independen, atau keduanya mempunyai distribusi normal atau tidak. Model regresi yang baik adalah distribusi data normal atau mendekati normal. Data terdistribusi normal dapat dilihat jika nilai Probability Jargue-Bera $>0,05$, maka data terdistribusi secara normal, sebaliknya jika nilai Probability Jargue-Bera $<0,05$, maka data tidak terdistribusi secara normal.

Tabel. 4.4

Hasil uji Normalitas Data

\begin{tabular}{|c|c|c|c|}
\hline Variabel & $\mathbf{N}$ & Jarque-Bera & Probabilitas \\
\hline CR & 4 & 787.1272 & 0.000000 \\
\hline DER & $\begin{array}{l}4 \\
0\end{array}$ & 8.493377 & 0.014312 \\
\hline NPM & 4 & 36.42775 & 0.000000 \\
\hline
\end{tabular}

Sumber : Data Diolah, Lampiran 2.

Dilihat dari Tabel 4.4 di atas pada probability CR, DER dan
NPM bernilai nol berarti data untuk variabel tersebut tidak normal karena syarat untuk normal adalah probability jargue-bera > 0,05 .Untuk menormalkan data $C R$, DER maka data asli di transformasikan dengan menggunakan transformasi logaritma normal $=L N($ data asli $)$ dan NPM menggunakan transformasi squerd $=S Q R T$ (data asli). Maka hasil dari pengolahan di lihat di bawah ini.

Tabel 4.5

Hasil Uji Normalitas Data

\begin{tabular}{|c|c|c|c|}
\hline Variabel & N & $\begin{array}{c}\text { Jarque- } \\
\text { Bera }\end{array}$ & Probabilitas \\
\hline CR & 39 & 4.080264 & 0.130012 \\
\hline DER & 39 & 2.001496 & 0.367604 \\
\hline NPM & 39 & 1.619157 & 0.445046 \\
\hline
\end{tabular}

Sumber, Data diolah, Lampiran 3

Dari tabel 4.5 di atas bahwa data variabel dalam penelitian ini normal, dimana probability $>0.05$ sehingga data dapat dikatakan berdistribusi normal.

\section{Pengujian Multikolinearitas}

Tujuan dilakukannya pengujian ini adalah untuk mengetahui apakah sesama variabel independen terjadi korelasi atau hubungan antara satu variabel dengan variabel lain. Uji ini dilakukan apabila kita memiliki independen lebih dari satu. Syarat tidak terjadi multikolinearitas adalah jika nilai korelasi antar variabel independen $<0,8$. Jika nilai korelasi > 0,8 maka terjadi multikolinearitas. (Gujarati, 2003). 
Tabel 4.6

Hasil Uji Multikolinearitas

\begin{tabular}{|c|c|c|}
\hline & $\mathrm{X} 1$ & $\mathrm{X} 2$ \\
\hline $\mathrm{X} 1$ & 1 & - \\
& & 0.2506146672 \\
& & 334638 \\
\hline $\mathrm{X} 2$ & - & 1 \\
& 0.2506146672 & \\
& 334638 & \\
\hline
\end{tabular}

Sumber: Data Diolah, Lampiran 4

Berdasarkan hasil olahan data pada Tabel 4.6 terlihat nilai korelasi antara sesama variabel independen dibawah 0,8 sehingga dapat dikatakan bahwa sesama variabel independen tidak memiliki hubungan multikolinearitas.

\section{Pengujian Autokorelasi}

Uji ini digunakan untuk melihat ada tidaknya autokorelasi, otokorelasi adalah korelasi yang terjadi antara anggota-anggota dari serangkaian pengamatan yang tersusun dalam data time series. Apabila terjadi otokorelasi di dalam suatu model, artinya varian sampel tidak menggambarkan varian populasinya. Dalam keadaan seperti ini model regresi yang dihasilkan tidak dapat digunakan untuk menaksir nilai variabel dependen pada variabel independen tertentu. Model penelitian yang baik adalah tidak terjadi otokorelasi. Untuk mendeteksi gejala otokorelasi digunakan Durbin-Watson Statistic Test. Jika DurbinWatsonnya antara -2 sampai 2 berarti tidak terjadi otokorelasi. (Gujarati, 2003).
Tabel. 4.7

Hasil Uji Durbin -Watson

\begin{tabular}{|r|c|}
\hline Model & Durbin watson \\
\hline 1 & 1.446933 \\
\hline Sumber: Data Dioalah,Lampiran 6 \\
Dari uji Durbin-watson pada \\
Tabel 4.7 terlihat bahwa tidak \\
terjadi Autokorelasi karena nilai \\
Dw antara $-2<1.446933<2$.
\end{tabular}

\section{Pengujian Heteroskedastisitas}

Uji heteroskedastisitas digunakan untuk menguji apakah model regresi terjadi kesamaan variance dari residual suatu pengamatan ke pengamatan yang lain (Ghozali, 2005). Jika Variance dari residual satu pengamatan ke pengamatan lain tetap, maka disebut homoskedastisitas dan jika berbeda disebut heteroskedastisitas.

Tabel. 4.8

Hasil Uji Heteroskedastisitas

\begin{tabular}{|l|l|l|l|}
\hline $\begin{array}{l}\text { F- } \\
\text { statistic }\end{array}$ & 4.413446 & $\begin{array}{l}\text { Prob. } \\
\mathrm{F}(2,37)\end{array}$ & 0.0193 \\
\hline $\begin{array}{l}\text { Obs*R- } \\
\text { squared }\end{array}$ & 7.679515 & $\begin{array}{l}\text { Prob. Chi- } \\
\text { Square(2) }\end{array}$ & 0.0215 \\
\hline \multicolumn{3}{|c|}{ Sumber : Data diolah, Lampiran 5 } \\
\multicolumn{4}{c|}{ Pada Tabel 4.8 terlihat tidak } \\
terjadi heteroskedastisitas karena \\
nilai probability Obs*R-squared \\
yaitu 7.679515 >0,05.
\end{tabular}

\section{Regresi Linear berganda}

Pada penelitian ini, teknik analisis data dilakukan dengan menggunakan teknik analisis regresi linear berganda untuk mengolah dan membahas data yang telah diperoleh dan untuk menguji hipotesis yang diajukan. Variabel C merupakan Constant (konstan), NPM (Net Profit Margin) merupakan variabel Y, CR (Current Ratio) 
merupakan variabel X1, DER (Debt to Equity Ratio) merupakan variabel X2, coefficient (koefisien) merupakan parameter dari permasalahan, Probabilitas (Probability) adalah angka yang menunjukkan kemungkinan terjadinya suatu kejadian.

Tabel 4.9

Hasil Uji Regresi Linear Berganda

Dependent Variable: $Y$

Method: Least Squares

Date: 10/19/17 Time: 16:51

Sample (adjusted): 139

Included observations: 39 after adjustments

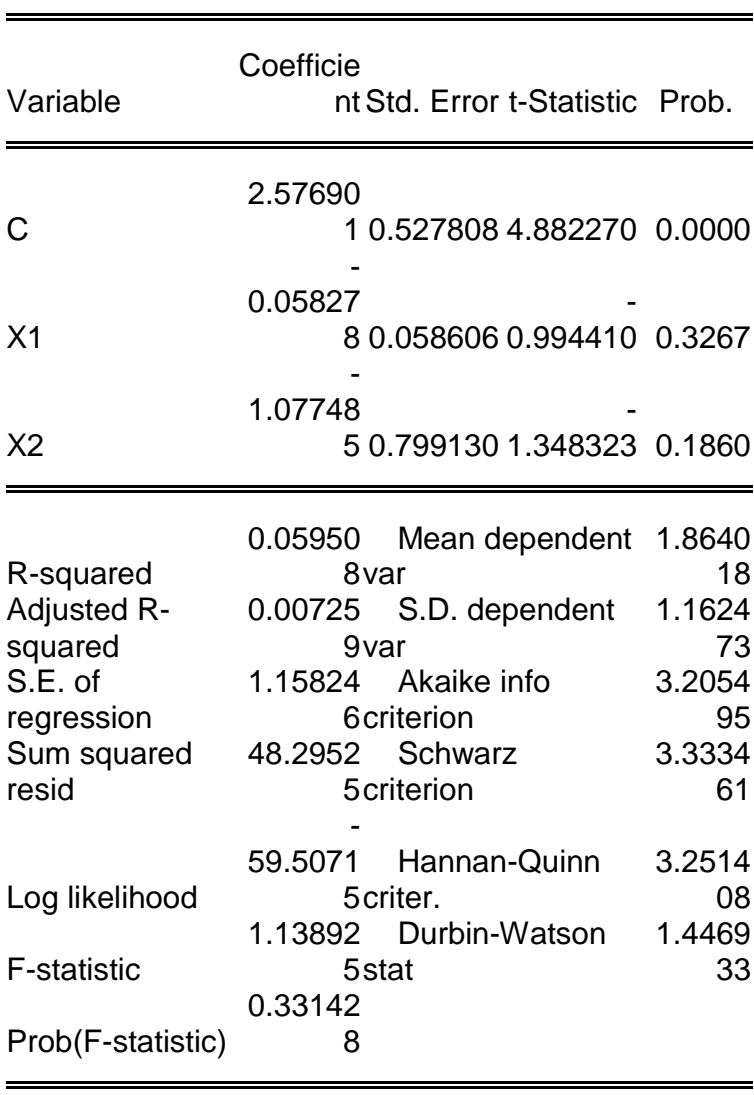

Sumber : Data Eviews

Pada tabel diatas, maka dapat dituliskan persamaan sebagai berikut :

$\mathrm{NPM}(\mathrm{Y})=2.576901-0.058278 \mathrm{X} 1-$ $1.077485 \mathrm{X} 2$

Nilai kostanta sebesar 2.576901 berarti bahwa nilai variabel $\mathrm{Y}$ adalah sebesar
2.576901 dengan asumsi variabel CR dan DER bernilai nol.

Nilai koefisien regresi Current Ratio (X1) sebesar -0.058278 maksud nya adalah setiap peningkatan $1 \%$ Current ratio, maka akan mengakibatkan penurunan Net Profit Margin (NPM) sebesar $-5.82 \%$.

Nilai koefisien Debt To Equity Ratio (X2) sebesar -1.077485 maksudnya adalah setiap peningkatan 1\% Debt To Equity Ratio, Maka akan mengakibatkan penurunan Net Profit Margin (NPM) sebesar $-107.74 \%$. dalam hal ini faktor-faktor lain yang mempengaruhi NPM dianggap tetap.

\section{Hasil Pengujian Hipotesis Pengujian Koefisien Regresi Secara Simultan (F)}

Dari Tabel 4.9 dihasilkan nilai $F$ Statistic sebesar 1.138925 dengan nilai signifikansi probability $F$ Statistic adalah 0.331428 , tingkat probabilitasnya lebih besar dari 0,05 atau > 0,05. Hal tersebut mengindikasikan bahwa semua variabel independen (CR dan DER) berpengaruh yang tidak signifikan terhadap variabel dependen (NPM).

\section{Pengujian Koefisien Secara Parsial (t)}

Uji $\mathrm{t}$ digunakan untuk menguji pengaruh variabel independen secara parsial terhadap variabel dependen, yaitu pengaruh dari variabel indenpenden untuk mengetahui pengaruh variabel bebas secara parsial terhadap variabel terikatnya. Dimana variabel independen atau varibel bebasnya adalah current ratio (CR) dan debt to equity ratio (DEP) sedangkan variabel dependen atau variabel terikatnya adalah net profit margin (NPM).

Pada hipotesis pertama pada penelitian ini adalah diduga current ratio berpengaruh signifikan negatif terhadap net profit margin. Dari hasil pengolahan data dihasilkan current 
ratio menunjukkan $\mathrm{t}$ hitung -0.994410 dengan nilai yang tidak signifikan 0.3267 lebih dari tingkat alpha 0.05 dan koefisien $\beta$ sebesar -0.058278 menunjukkan nilai negatif. Artinya Ha ditolak dan $\mathrm{HO}$ diterima yaitu current ratio berpengaruh negatif dan tidak signifikan terhadap net profit margin.

Pada hipotesis kedua pada penelitian ini adalah diduga debt to equity ratio berpengaruh singnifikan negatif terhadap net profit margin. Dari hasil pengolahan data yang dihasilkan debt to equity ratio menunjukkan $\mathrm{t}$ hitung -1.348323 dengan nilai yang tidak signifikan 0.1860 lebih dari tingkat alpha 0.05 dan koefisien $\beta$ sebesar -1.077485 menunjukkan negatif. Artinya $\mathrm{Ha}$ ditolak dan $\mathrm{H} 0$ diterima yaitu debt to equity ratio berpengaruh negatif dan tidak signifikan terhadap net profit margin.

\section{Koefisien Determinan $\left(\mathbf{R}^{2}\right)$}

$\mathrm{R}^{2}$ (R-Square) digunakan untuk mengukur seberapa besar proporsi variasi dari variable independen secara bersama-sama dalam mempengaruhi variable dependen. Dari hasil pengolahan data ditemukan nilai $R$-squared 0.059508 ini berarti bahwa variabel bebas CR (Current Ratio) dan DER (Debt To Equity ratio) mempengaruhi NPM (Net Profit Margin) sebesar $5.95 \%$ sedangkan sisanya $94.05 \%$ dipengaruhi oleh QR(Quick Ratio),CR(Cash Ratio),DAR(Debt To Assets Ratio).

\section{Pembahasan}

\section{Pengaruh Current Ratio terhadap Net Profit Margin}

Dari Tabel 4.8 dihasilkan nilai koefisien regresi untuk variabel Current Ratio sebesar -0.058278 bertanda negatif dengan nilai Net Profit Margin $0.3267>0,05$ yang berarti bahwa Current Ratio mempunyai pengaruh negatif yang tidak signifikan terhadap Net Profit Margin. Dengan demikian dapat disimpulkan hipotesis pertama ditolak.

Hasil penelitian ini sama dengan penelitian yang dilakukan oleh Abdul Kadir yang menemukan bahwa current ratio (CR) tidak mempunyai pengaruh yang siqnifikan terhadap net profit margin (NPM).

Dan penelitian yang dilakukan Erma Risdo Tohonan,dkk (2012) yang menemukan bahwa secara parsial likuiditas tidak berpengaruh signifikan terhadap profitabilitas.

Penelitian ini juga sama dengan penelitian yang dilakukan oleh Romdayanah (2011) dimana likuiditas berpengaruh positif dan tidak signifikan terhadap profitabilitas bank syari'ah.

Pengaruh Debt To Equity Ratio terhadap Net Profit Margin

Dari Tabel 4.8 dihasilkan nilai koefisien regresi untuk variabel Debt To Equity Rasio sebesar -1.077485 bertanda negatif dengan nilai Net Profit Margin $0.1860>0,05$ yang berarti bahwa Debt To Equity Ratio mempunyai pengaruh negatif yang tidak signifikan terhadap Net Profit Margin . Dengan demikian dapat disimpulkan hipotesis kedua ditolak.

Hasil penelitian sama dengan yang dilakukan oleh Abdul Kadir yang menyatakan bahwa debt to equity ratio (DER) tidak mempunyai pengaruh yang siqnifikan terhadap net profit margin (NPM) 
Penelitian ini berbeda dengan penelitian yang di lakukan Erma Risdo Tohonan,dkk (2012) menunjukkan bahwa secara parsial solvabilitas berpengaruh signifikan terhadap profitabilitas. Hal ini disebabkan karena terlalu banyak hutang yang dibayarkan perusahaan sehingga resiko finansial yang ditanggung perusahaan juga akan semakin besar begitu juga sebaliknya semakin rendah rasio ini maka profitabillitas perusahaan akan meningkat (Syamsudin,2001).

Dan penelitian dari Ruzaini Abdi Laksono (2013) menemukan bahwa secara parsial solvabilitas berpengaruh positif dan signifikan terhadap rentabilitas (profitabilitas).

\section{KESIMPULAN DAN SARAN Kesimpulan}

Current Ratio mempunyai pengaruh negatif yang tidak signifikan terhadap Net Profit Margin yang ditunjukkan dengan nilai Net Profit margin lebih besar dari 0,05 yaitu sebesar 0.3267 .

Debt To Equity Ratio mempunyai pengaruh negatif yang tidak signifikan terhadap Net Profit Margin yang ditunjukkan dengan nilai Net Profit Margin lebih besar dari 0,05 yaitu sebesar 0.1860 .

\section{Saran}

1. Bagi Manajemen, dalam rangka meningkatkan profitabilitas perusahaan, pihak manajemen harus memperhitungkan komposisikomposisi Debt to equity Ratio. Karena rasio tersebut dapat digunakan oleh para investor sebagai pertimbangan sebelum melakukan investasi pada perusahaan. Karena apabila rasio tersebut dalam kondisi optimal, maka kinerja operasional dan profitabilitas akan meningkat.

2. Bagi Para Investor, perusahaan yang baik adalah perusahaan yang mampu menghasilkan profit besar, meskipun dengan Debt to equity Ratio yang rendah, perusahaan tersebut mampu menutup semua kebutuhan modalnya dengan aset yang dimilikinya. Sehingga investor sebaiknya juga melihat perusahaan dari rasio tersebut, karena mengindikasikan kinerja perusahaan. Profit merupakan cerminan dari kinerja perusahaan, maka dari itu investor dan manajer hendaknya mempertimbangkan informasi yang terkait dengan kinerja keuangan perusahaan terutama Debt to equity Ratio yang berpengaruh pada peningkatan profit.

3. Bagi peneliti selanjutnya, diharapkan melakukan penelitian lanjutan dengan memperluas sampel dan data penelitian. Misalnya dengan menggunakan periode pengamatan yang lebih panjang serta menambahkan variabel independen lain yang diduga mempengaruhi profitabilitas.

\section{DAFTAR PUSTAKA}

Afrinda, Nidya. 2013. Analisis Pengaruh Likuiditas dan Solvabilitas Terhadap Profitabilitas pada Perusahaan Makanan dan Minuman yang Terdaftar di Bursa Efek Indonesia. Palembang

Afriyeni, Endang. 2008.Penilaian Analisis Kinerja Dengan Menggunakan Analisis Rasio.JurnalEkonomi dan Bisnis. Vol 3 No 2.

Baridwan, Zaki. 2000.

IntermediateAccounting. BPFE. Yogyakarta

Cooper, Donald R. dan Schindler, Pamela.2008, Business Research 
Methods, McGraw-Hill Companies, Inc. New York.

Danil, A., \& Yusra, I. (2019). Pengaruh kausal antara ukuran perusahaan, nilai buku dan likuiditas saham di Bursa Efek Indonesia. INA-Rxiv.

Djoehar, Ainun. 2014. Analisis Kinerja Keuangan pada Perusahaan Telekomunikasi yang Terdaftar di Bursa Efek Indonesia Periode 20092013. Malang.

Fahmi, Irham. 2011. Analisis LaporanKeuangan. Bandung: Alfabeta.

Gusnita, E., \& Martha, L. (2019). Analisis Struktur Modal Dalam Memoderasi Pengaruh Kepemilikan Manajerial Dan Pertumbuhan Perusahaan Terhadap Nilai Perusahaan Di Indonesia. INARxiv.

Hadya, R. (2013a). Pengaruh Harga dan Risiko Saham Terhadap Likuiditas Saham Pada Perusahaan-Perusahaan Yang Terdaftar Di Bursa Efek Indonesia. Jurnal KBP, 1(2), 208-231.

Hadya, R. (2013b). Pengaruh Harga dan Risiko Saham terhadap Likuiditas Saham Pada Perusahaan-Perusahaan Yang Terdaftar Di Bursa Efek Indonesia. Jurnal KBP, 1(2), 208-231. Retrieved from https://akbpstie.ac.id/cmsz/medias/file/ 9. rizka hadya.pdf

Hadya, R. (2014a). Analisis likuiditas, solvabilitas, nilai pasar dan return saham: studi empiris pada perusahaan sektor perbankan yang terdaftar di Bursa Efek Indonesia. Jurnal Riset Manajemen Dan Akuntansi, 3(1), 107118.

Halim, Abdul. 2008.Akuntansi Sektor Publik: Akuntansi Keuangan Daerah. Salemba Empat.Jakarta Selatan.

Hamidu, Novia. 2013.Pengaruh Kinerja Keuangan Terhadap Pertumbuhan LabaPadaPerbankan di BEI. Jurnal
EMBA. Vol.1 No.3 Juni 2013, Hal. 711-721.

Hanafi, D., \& Yusra, I. (2019). Tangibility, liquidity, growth opportunity, dan leverage: studi pada perusahaan terdaftar di Bursa Efek Indonesia. INARxiv, (2001).

Hanafi, Mahmud. 2007.Analisis Laporan Keuangan. Liberty. Yogyakarta

Harahap, Sofyan Syafri. 2001. TeoriAkuntansi: Laporan Keuangan. Jakarta: PT Raja Grafindo Persada.

Harrison, et. al. 2011. Akuntansi Keuangan (INTERNATIONAL FINANCIAL REPORTINGSTANDARS-IFRS).

Erlangga. Jakarta.

Hilman, Rodif dkk. 2014.Kinerja Keuangan Menggunakan Analisis Rasio Likuiditas,Solvabilitas,Aktivitas dan Profitabilitas untuk pengambilan Keputusan pada PT PLN Area Manado.Jurnal EMBA 283 Vol.2 No.1 Maret 2014, Hal. 283-294

Ikatan Akuntan Indonesia 2009, Standar Akuntansi Keuangan Entitas Tanpa Akuntabilitas Publik, Dewan Standar Akuntansi Keuangan Ikatan Akuntan Indonesia, Jakarta.

Ikhsan, Irfan dan Prianthara IB Teddy. 2009.Akuntansi untuk Manajer.Graha Ilmu. Yogyakarta.

Indrianto, Nur dan Bambang Supomo. 2002.Metodologi Penelitian Bisnis untuk Akuntansi danManajemen. BPPE. Yogyakarta.

Jumingan. 2009.Analisis Laporan Keuangan. PT. Bumi Aksara. Jakarta.Kamaludin, dan Indriani Rini. 2012.Manajemen Keuangan Konsep Dasar dan Penerapannya.Bandar Maju. Bandung. Junita, Silvi dan Siti Khairani. 2012. Analisis Kinerja Perusahaan dengan Menggunakan Analisa Rasio Keuangan pada Perusahaan Telekomunikasi yang Terdaftar di 
Bursa Efek Indonesia Periode 20082011.

Jusuf, Jopie. 2014. Analisis Kredit untukCredit. Gramedia. Jakarta

Kamaludin dan Rini Indriani 2012, Manajemen Keuangan "Konsep Dasar dan Penerapannya", Cetakan Ke-7, CV. Mandar Maju, Bandung.

Kasmir. 2009.Analisis Laporan Keuangan. Rajawali Pers. Jakarta.

Kasmir 2010, Analisis Laporan Keuangan, Cetakan Ke-3, PT. Rajagrafindo Persada, Jakarta.

Kasmir. 2013. Analisis Laporan Keuangan.Jakarta: PT. Raja Grafindo Persada.

Khafidz, Mansur. 2015. Pengaruh Likuiditas dan Solvabilitas Terhadap Profitabilitas (Studi pada Perusahaan Subsektor Telekomunikasi yang Terdaftar di Jakarta Islamic Index (JII) Periode 2010-2014. Semarang.

Kieso, Donald E. Jerry J.Weygandt \& Terry D.Warfield, 2001. "Intermediate Accounting". 10th edition, diterjemahkan oleh Salim, Emil. 2002. Akuntansi Intermediate. Jilid Dua, Edisi Kesepuluh. Jakarta: Erlangga.

Kuncoro, Mudrajat. 2011. Metode Kuantitatif. Yogyakarta: UPP-STIM YKPN

Laksono, Ruzaini Abdi. 2012. Pengaruh Likuiditas dan Solvabilitas Terhadap Rentabilitas pada KPRI Bhakti Husada pada Tahun 2008-2012. Semarang

LSMAP 2010, Pengertian Laporan Keuangan dan Analisis Laporan Keuangan, Diakses 04/12/12, http://lsmap.wordpress.com/2010/03/0 1/pengertian-laporan-keuangan/Maith, Hendry Andres. 2013.Analisis Laporan Keuangan Dalam Mengukur Kinerja Keuanganpada PTHanjaya Sampoerna. Jurnal EMBA Vol.1 No.3 September 2013, Hal. $619-628$
Manurung, Erma Risdo Tohonan, dkk. 2012. Pengaruh Likuiditas dan Solvabilitas Terhadap Profitabilitas pada Perusahaan Real Estate dan Property Bursa Efek Indonesia. Pekanbaru.

Mardiasmo. 2002.Akuntansi Sektor Publik. PenerbitAndi. Yogyakarta.

Margareta, Farah.2014.Dasar-dasar Manajemen Keuangan. PT. Dian Rakyat. Jakarta.

Mulfita, A., \& Yusra, I. (2019). Analisis regresi data panel terhadap likuiditas saham di Indonesia. INA-Rxiv.

Munawir, S. 2002. Analisis Laporan Keuangan(Edisi ke-4). Liberty.Yogyakarta.

Munawir. 2004. AnalisisLaporan

Keuangan. Liberty. Yogyakarta.

Prastowo, Dwi. 2005.Analisis Laporan Keuangan Konsep dan Aplikasi. YPKN. Yogyakarta.

Prihadi, Toto. 2008. DeteksiCepat Kondisi Keuangan 7 Analisis Rasio Keuangan. PPM. Jakarta.

Purnama, S., \& Mayliza, R. (2019). Nilai Perusahaan Di Lihat Dari Aspek Profitabilitas, Ukuran Perusahaan Dengan Struktur Modal Sebagai Variabel Intervening. INA-Rxiv.

Putra, I., \& Yusra, I. (2019). Analisis likuiditas saham menggunakan regresi data panel. INA-Rxiv.

Riyanto, Bambang. 2004.Dasar-Dasar PembelajaranPerusahaan.Edisi

Ketiga. Yogyakarta:PenerbitYayasan Badan Penerbit Gajah Mada.

Riyanto, Bambang. 2008.Dasar-dasar Pembelajaran Perusahaan.BPPE. Yogyakarta.

Rudianto.2012.Pengantar Akuntansi : Konsep dan Teknik Penyusunan Laporan Keuangan.Erlangga. Jakarta.

Saputra, J., \& Martha, L. (2019). Analisis Kinerja Keuangan Dan Nilai Perusahaan, Serta Pengaruhnya Terhadap Harga Saham. INA-Rxiv. 
Suhartono, \& Yusra, I. (2019). Analisis perbandingan kinerja keuangan bank konvensional dengan bank syariah yang terdaftar di BEI. INA-Rxiv, 1-9.

Sunyoto, Danang. 2013. Analisis Laporan Keuangan untuk Bisnis. Yogyakarta : CAPS

Saraswati, Dinastya dkk. 2013.Analisis Laporan Keuangan Sebagai Alat Penilaian KinerjaKeuangan Pada Koperasi(STUDI PADA KOPERASI UNIVERSITAS

BRAWIJAYAMALANG PERIODE 2009-2012). Jurnal Administrasi Bisnis (JAB) Vol. 6 No. 2.

Sawir, Agnes. 2005. Analisa kinerja Keuangandan Perencanaan Keuangan Perusahaan. Jakarta: PT Gramedia Pustaka Utama.

Sugiyono, 2008, Statistika untuk Penelitian, CV Alvabeta. Bandung

Wahyudi, R., \& Martha, L. (2019). Analisis Modal Intelektual Dan Kinerja Keuangan Dan Pengaruhnya Terhadap Nilai Perusahaan. INA-Rxiv.

Weston, J.Fred. \& Eugene F. Brigham, 2010.Dasar-dasar manajemen Keuangan. Jakarta: Erlangga.

Yusra, I., Hadya, R., Begawati, N., \& Istiqomah, L. (2019). Panel data model estimation: the effect of managerial ownership, capital structure, and company size on corporate value Panel data model estimation: the effect of managerial ownership, capital structure, and company size on corporate value. Journal of Physics: Conference Series, 1175 , $1-6$. https://doi.org/10.1088/17426596/1175/1/012285

Yusuf, D., \& Yusra, I. (2019). Faktor-faktor yang mempengaruhi struktur modal perusahaan. INA-Rxiv. 